\title{
What Will You Do?
}

Why does one write about one's own life experience for everyone to read and to criticize? Well, for many reasons, not the least of which is the hope that it may be a guide point for those beginning a Canadian prison sentence. Someone needs to set the record straight and it might as well be me. I have a wish within the covers of this journal to air Correctional Service Canada's (CSC) linen, to expose injustices and reveal to the public what they try so hard to keep covered up. I will simply start at the beginning of entering a CSC penitentiary and continue to the present time. I shall write of events as I saw them and reveal things that will shock the general public who have altruistic views of CSC mainly because they have been lied to for so long. Well the curtain is about to be lifted. I feel the need to speak for all the people who have been threatened and forced into silence, violating their rights to freedom of speech. Perhaps you think prisoners deserve to be beaten, raped and repeatedly mistreated by those in power, but being locked up, separated from society and life as punishments are sufficient. Two wrongs do not make a right and it is hypocritical thinking to wish harm on prisoners who are in extremely vulnerable positions. After reading this you might choose to do nothing and that is also your choice, but hopefully you will be part of the solution, not the problem. As Dr. Martin Luther King once noted is his 1963 letter from the Birmingham Jail, "Injustice anywhere is a threat to justice everywhere".

I entered CSC first via provincial jail. When I first got to this specific institution I was taken to admissions and I noticed a lot of the guards were sitting around. The guards, including female ones, made degrading jokes and comments about the prisoners' genitalia. The supervisors just stood there watching and laughing along with these guards. Prisoners' personal property were seized and we were supposed to receive seizure slips, but none were provided. Our property went home with the guards as one openly admitted that "My son would love your shoes". Five years later the property was never found. One younger prisoner was sexually assaulted by a male guard when his penis was grabbed extremely hard. His genitals were also squeezed until he could hardly walk. He made a formal complaint and it was his word against those of multiple guards. Do you see the problem? We were told we were not allowed to have pillows and were taken to our cells.

We must harass the guard to let us go to the library. The library has a budget of only $\$ 300$ per year to buy new books. Citizens from outside 
want to donate books, but staff make it extremely difficult by giving lame and pathetic excuses. I asked one staff member what the real reason it is so hard to get new books in the library and I was told "we just don't like prisoners". Well then why work in prisons if you "don't like prisoners?" It is like working as a teacher when you do not like kids. Get out, find a new job. Prisoners are extremely vulnerable and need help with their lives, not guards constantly trying to ruin prisoners' lives to make sure we never get out. It is utterly pathetic and CSC needs to weed out the problem guards. Hire only extremely qualified guards who have compassion and brains. Yes, all guards get the same training, but not all have the right personality to work with prisoners. Trust me when I say a large majority of guards play mind games and power games.

Imagine if police had complete control over your life 24/7 and controlled every bit of evidence you had against them. Prisoners can file three levels of grievances. Level one is handled by supervisors and are denied the vast majority of the time. Now keep in mind these supervisors are friends with most guards, and go to their homes for BBQs and parties. So, when a prisoner files a complaint against a guard, the prisoner is immediately targeted. Retaliation is almost always carried out by said guard's colleagues. One prisoner filed a complaint because guards were repeatedly banging on his door all night. They lied and said they needed to make sure he was "breathing", but it is all bullshit and just an excuse to harass him. This prisoner made a second level complaint and was called into the office to speak with a supervisor who warned him that all the other guards would start banging on his door if he did not stop complaining. This took three months for the prisoner to get to see the supervisor to talk about his issues. If he were to make a third level complaint, he would literally have to wait at least one year to get a response from Ottawa - a full year! And this is when things are moving 'normally'. At this time, we continue to receive notices that "Due to high levels of complaints your wait time has been extended". One prisoner had to wait 16 months. Unbelievable. Supervisors almost always side with their staff and prisoners have practically nobody to help us.

There is the Correctional Investigator of Canada who "investigates" prisons, but when we write to him we often have to wait until he visits the institution in three months. When he finally does come here, he must announce himself so he will not surprise the staff and he only sees prisoners for a few minutes. It is very rushed and he claims he can only 
write recommendations and has no real power. He told me personally that even if he did write good recommendations that CSC could just ignore them. So, what is the point of having correctional investigators? The Office of the Correctional Investigator needs real power. Right now, it seems he just exists for show, so that the public believes someone is "investigating" prisons. Prisoners feel his office is useless.

CSC staff frequently listen to prisoners' private telephone calls. Now you might think this is allowed, but it is not unless they have a warrant from the warden. If the warden authorizes it, CSC staff can listen in because all telephone conversations are stored in the computer. However, CSC staff needs to give prisoners notice within 30 days, but nobody monitors the staff's access to the telephone recording system. So basically CSC staff can listen to all our telephone conversations and just ignore procedure that requires the warden's permission.

Prisoners are only supposed to be sent to segregation for very serious offenses, such as violence, but if a certain guard does not like a prisoner he will just make a split-second decision to send the person to segregation. They will fabricate reasons afterwards. Segregation after two weeks is considered torture according to human rights organizations, but CSC does whatever it wants and is above the law. Prisoners suspected of having smuggled drugs into the institution are sent to "dry cells" where they are forced to defecate in front of guards or they will not be allowed to leave. Simply a guard's suspicions can get a prisoner sent to dry cells. This should not be allowed. It is degrading and humiliating. If the prisoner cannot defecate he is forced to lay on a metal bed with fluorescent lights on $24 / 7$. Torture charges need to be laid against CSC staff.

Many places in the prison are void of cameras, which should never be the case. Because guards take prisoners to these secret locations and abuse them in various ways, and even claim "self defense". Guards also smuggle or plant drugs, cell phones, alcohol and cigarettes into prisons, among other unprofessional activities. Again, charges need to be laid.

Prisoners food menu are constantly being diminished. Every year the food gets smaller and smaller. It also gets lesser and lesser in quality. When prisoners go to segregation they get almost no food as punishment. We are supposed to have milk at all meals, but in segregation prisoners get just one tiny Styrofoam cup of milk and no fruit. We used to receive over $100 \$$ per 
month for working, now we receive just a fraction of that every two weeks. It is basically slave labour because if one refuses to work they are refusing to cooperate with their correctional plan and cannot move to lower security levels. Prisoners also get locked up for 10 days if they refuse to work. Slave labour. Disgusting.

Each range is controlled by a control room bubble. This guard opens prisoners' doors. If the guard does not like a certain prisoner, they will give the prisoner rude gestures and refuse to open their door. The result is prisoners being deprived of the washroom. When complaints are made, denials follow and it is once again covered up. Retaliation results. When "boil water advisories" are sent to institutions, the guards refuse to tell us. At 9:00pm we hear it on the news and it is too late. Again, nothing is done. Guards sit in the control bubble and smoke even though it is not allowed. They use their cell phones even though it is not allowed on property. In transports, guards frequently give "rough rides" where prisoners are thrown around inside buses and our bodies sustain injuries. Again, nothing is done. Food is also withheld from prisoners if guards do not like certain prisoners. Guards yell "I don't give a fuck if you don't have a meal".

Staff in the mail room tamper with "privileged" mail. CSC cannot open privileged mail from lawyers for example. So, the mail room opens it, then puts is inside a new envelope and seals it so prisoners will not know. This goes against the rules, but who will stop these people? They also use x-ray equipment to read privileged mail. Also, mail is "lost" or stolen by guards. All CSC has to do is claim that something is being done "for security reasons" and they can get away with literally anything. Staff also insult ridicule, taunt and harass prisoners on a daily basis. Nothing is ever done to discourage these practices. Supervisors literally just laugh when this happens. We are doing our time and working on our issues and have the right to do our time without being harassed.

The dentist is another problem. There is only one dentist for hundreds of prisoners. Men's teeth are falling out their heads. Nerve pain, cavities - nothing is fixed for six months usually. Excuses such as "CSC assesses priorities first". CSC is extremely cheap and needs to hire more than one dentist. Canadian prisoners are treated like third world prisoners. The healthcare is horrendous. It is embarrassing that Canadians have such bad healthcare for prisoners. CSC puts on a good show for the public, but the 
healthcare is deplorable. If a complaint is made against the dentist, he will refuse to see that prisoner for an entire year until the complaint is resolved, leaving the prisoner in excruciating pain. Torture.

The doctor should lose his medical license. He is nicknamed "the butcher" because he destroys people's bodies. He refuses to help certain prisoners. Torture, once again. Legal aid will not pay for prisoners who want to file lawsuits so they have no resources to fight CSC unless family or friends pay the thousands of dollars in court fees. CSC sees to it that prisoners remain cut off from resources and money.

When CSC officials do not like a certain prisoner, they will just transfer him to a different institution even if it is on the other side of the country. Even though CSC requires a reason they will just claim "security concerns" and get rid of the person for no actual reason except to be nasty. Meanwhile, this individual's life is uprooted and severely disrupted. This entire bureaucratic system is extremely corrupt and the swamp needs to be drained. Here are some suggestions:

1. Have cameras everywhere. Make sure the video files are not erasable and saved in a computer, so Ottawa can always have access to them. One staff member at a certain institution should not have control. CSC staff are too corrupt for one person to have control of the video files.

2. Have severe consequences for CSC staff who harass prisoners.

3. When prisoners go on the bus or transfers, make sure video cameras are present and functional so that at no time guards are alone with prisoners.

4. Start hiring appropriate health care staff - doctors, dentists and nurses. Fire the current ones who are problems. If you cannot be compassionate to prisoners do not work in prisons.

5. Stop putting prisoners in segregation. If it us absolutely necessary, then 14 days should be the maximum.

6. Have correctional investigators who actually have power, not just complaint puppets.

7. If guards insult prisoners or are caught taunting, lying or harassing others, then they must get discipline reports. After a certain amount of complaints they should be suspended. 
8. Stop threatening prisoners. If prisoners want to talk with media, why does CSC care so much? What does CSC have to hide?

9. Fix the complaint system. When guards file complaints against us, within 15 days we get convicted. When we file against them, it takes 15-16 months. This is ridiculous.

10. The warden frequently changes titles. They too need to be held to account instead of avoiding responsibilities because there are new administrators, new staff and new positions all the time.

I suggest that a prisoner advocacy group be able to come to the prison monthly to report on injustices. These complaints should be made public. The more transparent, the better. There is far too much secrecy within CSC. Also, CSC's slogan "Changing lives, protecting Canadians" is wrong. CSC does not change lives, they make prisoners' lives even more dysfunctional and unstable, not helping at all but making society even more unsafe. Programs are a complete joke. They are not readily taken up because many staff are unqualified. When/if programs are offered, they are not in English, but only in French in Quebec. Quebec guards frequently insult English prisoners because they do not speak French. Once prisoners are released, they are severely damaged by the entire CSC experience.

This letter has been written in the hope readers will try to help prisoners. The amount of cover ups, lies and pure deception fed to the public by CSC management to Canadians is unbelievable. It is my hope that I have helped in some small way to reveal the truth and open people's eyes by being a whistle blower.

\section{ABOUT THE AUTHOR}

Anonymous Whistleblower is imprisoned at Archambault Institution. 